\title{
The Copper: A Holistic View between of a Polluting Cation and a Healthy Ingredient
}

\author{
Dourtoglou Vassilis* \\ Professor, University of West Attica, Greece
}

Submission: April 01, 2019; Published: April 15, 2019

*Corresponding author: Dourtoglou Vassilis, Professor, University of West Attica, Greece

Keywords: Environmental issues; Agriculture; Climatic preservation; Living organisms; Metabolic functions; Copper

\section{Mini Review}

Facing to the increase demand of copper and the future uses, the environmental issues of this element should be considered. From computers to electric cars and from solar panels to wind energy the predicted impact to the global climatic preservation seems to be positive. As far as the mechanical and electric properties of the metal there is no doubt everything seems to be on the good way. Oxidation of the metallic copper produce copper cation, well known for his uses in agriculture and in human life. The raised question is: It is a polluting cation? Or is a pillar of healthy life.

Copper is an indispensable element for the living organisms in which perform specific metabolic functions. Because it is an essential element, daily dietary requirements have been recommended by the American Medical Association at 1.2$1.3 \mathrm{mg} /$ day. Copper cation is involved in the functions of many copper-dependent proteins, including transcriptional regulators, chaperones, oxidoreductases, mitochondrial electron transport and free radical scavenging [1]. Copper cation intakes have been declining and it appears that a large fraction of the population does not even consume the recommended daily allowance (RDA) for copper (0.9mg per day) let alone an optimal intake of copper (2.6mg per day). Thus, it appears that much of the population is at risk of inadequate but especially suboptimal intakes of copper [2].

In the USA, heart disease is the leading cause of death overall [3]. While research and medical practice has focused almost exclusively on cholesterol and dietary saturated fat as Ischemic Heart Disease risk factors, we may have overlooked an exceedingly simple, plausible and widespread condition, copper deficiency, as one cause, perhaps even a major cause. Avoidance of copper-rich foods may play a role in widespread copper insufficiency and deficiency and therefore may be linked to IHD via copper [1].
As it mentioned by DiNicolantonio [4] from the studies of Bugel et al. [5] healthy young women supplemented with 3 or $6 \mathrm{mg}$ of copper sulfate per day have a significant increase in superoxide dismutase activity in red blood cells and plasminogen activator inhibitor type 1 was significantly reduced.

Copper is used since three centuries as fungistatic and fungicide especially in grapes and stone fruits. Bordeaux mixture is an example of such application. Soils are overloaded in some cases with copper ions and old vine plants are plantaccumulators of copper. Despite of this soil contamination, wines and grapes does not accumulate much more copper cation than the permitted by the international studies and regulations.

Copper is an element and therefore cannot be degraded. In soil, copper is present in a number of forms partitioned between soil and solution. According to Commission Regulation 2015/232/EC, a review of European monitoring programs was provided and used to identify 'background levels' of copper present in soil from natural or anthropogenic sources other than the regulated use for the soil exposure assessments. Considering the representative uses 'background levels' were $160 \mathrm{mg} \mathrm{Cu} /$ $\mathrm{kg}$ soil (90th percentile) for grape and $26 \mathrm{mg} \mathrm{Cu} / \mathrm{kg}$ soil (90th percentile) for tomatoes and cucurbits [6]. The wine industry is one of the most concerned about agricultural uses of copper, so we will be focus on that. We will be also focus on this because there is a worldwide increase in wine demand and new players have come into this production and consequently more and more surface on the planet are susceptible to receive copper ion as fungicide. (China, India, South America, Australia, New Zeeland South Africa, etc.)

Some authors say that there are some agricultural techniques in the vineyard which include the use of copper compounds and can result in a higher level of copper residues in the grapes at harvest [7] although higher copper concentrations in the soil 
result in an increase of the copper levels in berries [8]. In other research almost no changes in the copper concentrations were found in the grapes, must or the wine from plants with a higher concentration in their leaves due to the sprays applied during the vegetation season [9]. The final copper in the wines was not at levels harmful to human health. In Efsa report is mentioned that further considerations are needed [10].

The legislative values are generally country specific. For example, the Organization International de la Vine et du Vin's (OIV) compendium of international methods of analysis sets a maximum acceptable limit for $\mathrm{Cu}$ of $1 \mathrm{mg} / \mathrm{L}$ in wine [11]. Considering that the recommended doses of wine is two glasses per day, a large portion of daily dietary requirements in copper can be acquired from the wine.

The French paradox [12] is a catchphrase [13], first used in the late 1980 s, that summarizes the apparently paradoxical epidemiological observation that French people have a relatively low incidence of coronary heart disease while having a diet relatively rich in saturated fats. It is believed that one of the components of red wine potentially related to this effect is resveratrol [14]; however, the authors of a 2003 study concluded that the amount of resveratrol absorbed by drinkers of red wine is small enough that it is unlikely to explain the paradox [14].

As a typical French diet contains liver (liver paste), oysters, green salads and wine and all these foods and drinks are rich in copper, copper may be associated with this effect and not with polyphenols and other wine compounds. We need more epidemiological research around the world to have a more accurate picture of the true role of copper ions in the environment and in human life.

\section{References}

1. Festa RA, Thiele DJ (2011) Copper: an essential metal in biology. Curr Biol 21(21): R877-R883.
2. Klevay LM (2011) Is the Western diet adequate in copper? J Trace Elem Med Biol 25: 204-212.

3. Chambers A, Krewski D, Birkett N, Plunkett L, Hertzberg R, et al. (2010) An exposure-response curve for copper excess and deficiency. J Toxicol Environ Health B Crit Rev 13(7-8): 546-578.

4. DiNicolantonio JJ, Mangan D, O’Keefe JH (2018) Copper deficiency may be a leading cause of ischaemic heart disease. Open Heart 5(2): e000784.

5. Bügel S, Harper A, Rock E, O'Connor JM, Bonham MP, et al. (2005) Effect of copper supplementation on indices of copper status and certain CVD risk markers in young healthy women. Br J Nutr 94(2): 231-236.

6. European Food Safety Authority (2018) Peer review of the pesticide risk assessment of the active substance copper compounds copper(I), copper (II) variants namely copper hydroxide, copper oxychloride, tribasic copper sulfate, copper(I) oxide, Bordeaux mixture. EFSA Journal 16(1): 5152.

7. Wightwick AM, Mollah MR, Partington DL, Allinson G (2008) Copper fungicide residues in australian vineyard soils. J Agric Food Chem 56(7): 2457-2464

8. Provenzano MR, El Bilali H, Simeone V, Baser N, Mondelli D, et al. (2010) Copper contents in grapes and wines from a Mediterranean organic vineyard. Food Chemistry 112(4): 1338-1343.

9. Pessanha S, Carvalho ML, Becker M, Bohlen A (2010) Quantitative determination on heavy metals in different stages of wine production by Total Reflection X-ray Fluorescence and Energy Dispersive X-ray 84 Fluorescence: Comparison on two vineyards. Spectrochimica Acta Part B: Atomic Spectroscopy 65(6): 504-507.

10. European Food Safety Authority (EFSA) (2018) Review of the existing maximum residue levels for copper compounds according to Article 12 of Regulation (EC) No 396/2005. EFSA Journal 16(3): 5212.

11. Clark AC, Wilkes EN, Scollary GR (2015) Chemistry of copper in white wine: a review Australian Journal of Grape and Wine Research 21(3): 339-350.

12. Wikipedia.

13. Wikipedia.

14. Goldberg DM, Yan J, Soleas GJ (2003) Absorption of three wine-related polyphenols in three different matrices by healthy subjects. Clin Biochem 36(1): 79-87.

Your next submission with Juniper Publishers will reach you the below assets

- Quality Editorial service

- Swift Peer Review

- Reprints availability

- E-prints Service

- Manuscript Podcast for convenient understanding

- Global attainment for your research

- Manuscript accessibility in different formats

( Pdf, E-pub, Full Text, Audio)

- Unceasing customer service

Track the below URL for one-step submission https://juniperpublishers.com/online-submission.php 